\title{
Update on Gatheter Ablation of Atrial Tachycardia, Atrial Flutter, and Beyond
}

\author{
Michael D. LESH, MD, FACG
}

\begin{abstract}
Atrial tachyarrhythmias represent a great challenge to successful treatment. It is important to recall that atrial tachycardia may occur by one of several mechanisms. Because of their poor response to medical therapy, atrial tachycardias are increasingly being approached with transcatheter ablation. For patients in whom drugs are ineffictive or intolerable, ablation of the His bundle had been an option. Unfortunately, while preventing rapid ventricular response, this procedure mandates the implantation of a permanent pacemaker and does nothing to restore normal hemodynamics to the atrium. The presence of either an isolated automatic focus or reentry with a protected zone of slow conduction implies that these forms of atrial tachycardia might be cured by targeting lesions at critical atrial tissue, without altering normal atrioventricular conduction.

The index arrhythmia(s) at which catheter ablation is to be directed should have been well-documented prior to invasive testing, since aggressive atrial stimulation will frequently induce non-clinical tachycardia as an artifact. One should deploy as many electrodes as possible given the constraints of recording systems. Placing multi-polar electrode catheters along regions of likely tachycardia origin, such as the crista terminalis (CT) in the RA may shorten the time required for mapping with a roving catheter. Multi-electrode arrays, such as an atrial "basket" catheter are being developed and should improve the efficiency of mapping. The following table summarizes the approach to ablation in patients with atrial arrhythmias, including the electrophysiologic method for chosing target sites and the commonest locations. The expected results and recurrence rates are based on reported results to date. Conclusions: Chronic medical therapy is usually not effective for atrial tachycardias. Results indicate that RF catheter ablation, by severing corridors of slow conduction or abolishing foci of abnormal automaticity, can safely treat atrial arrhythmias in man. Recurrence is not uncommon in patients with structural heart disease, the reasons for which require further investigation. Tachycardia-related cardiomyopathy reverses after successful ablation of automatic atrial tachycardia. Time will tell whether the most common atrial arrhythmia, atrial fibrillation, will ever be curable using catheter ablative techniques. However, early results indicate that catheter-based "maze" lesions, in the right atrium alone or in both atria, may prcvent the propagation of wandering wavelets. In some cases, atrial fibrillation is actually the result of a rapidly
\end{abstract}

From the Department of Medicine and the Cardiovascular Research Institute, University of California, San Francisco, USA. 


\begin{tabular}{|c|c|c|c|c|c|}
\hline Arrhythmia & $\begin{array}{l}\text { Approach to } \\
\text { targetting }\end{array}$ & Usual sites & $\begin{array}{l}\text { Fragmented } \\
\text { electrograms }\end{array}$ & $\begin{array}{l}\text { Acute } \\
\text { success }\end{array}$ & $\begin{array}{c}\text { Recurrence } \\
\text { rate }\end{array}$ \\
\hline $\begin{array}{l}\text { Focal automatic } \\
\text { atrial tachycardia }\end{array}$ & $\begin{array}{l}\text { Activation map- } \\
\text { ping; } \pm \text { Endocar- } \\
\text { dial pacemapping }\end{array}$ & $\begin{array}{l}\text { Crista terminalis, } \\
\text { opening of pul- } \\
\text { monary veins }\end{array}$ & +1 & $80-95 \%$ & $10-20 \%$ \\
\hline $\begin{array}{l}\text { Focal reentrant } \\
\text { atrial tachycardia }\end{array}$ & $\begin{array}{l}\text { Activation map- } \\
\text { ping; ?Endocar- } \\
\text { dial pacemapping } \\
\text { or "concealed en- } \\
\text { trainment" }\end{array}$ & $\begin{array}{l}\text { Crista terminalis, } \\
\text { coronary sinus os }\end{array}$ & $+H$ & $80-95 \%$ & $10-20 \%$ \\
\hline $\begin{array}{l}\text { Typical atrial } \\
\text { flutter }\end{array}$ & $\begin{array}{l}\text { Anatomic; con- } \\
\text { cealed entrain- } \\
\text { ment }\end{array}$ & $\begin{array}{l}\text { Isthmus btwn } \\
\text { IVC and tricuspid } \\
\text { ring }\end{array}$ & - & $95 \%$ & $10 \%$ \\
\hline $\begin{array}{l}\text { Macro-reentrant } \\
\text { atrial tachycardia } \\
\text { (post-congenital } \\
\text { heart surgery) }\end{array}$ & $\begin{array}{l}\text { Activation map- } \\
\text { ping followed by } \\
\text { concealed en- } \\
\text { trainment }\end{array}$ & $\begin{array}{l}\text { Near surgical } \\
\text { scars and/or ana- } \\
\text { tomic obstacles; } \\
\text { esp. atriotomy; } \\
\text { RF lesion must } \\
\text { bridge critical } \\
\text { isthmuis }\end{array}$ & $+1+$ & $70-80 \%$ & $10 \%$ \\
\hline $\begin{array}{l}\text { Sinus node reen- } \\
\text { try }\end{array}$ & $\begin{array}{l}\text { Activation map- } \\
\text { ping; }\end{array}$ & $\begin{array}{l}\text { Along crista } \\
\text { terminalis }\end{array}$ & + & $80-95 \%$ & $5-10 \%$ \\
\hline $\begin{array}{l}\text { Inappropriate si- } \\
\text { nus tachycardia }\end{array}$ & $\begin{array}{l}\text { Anatomic guided } \\
\text { by intracardiac } \\
\text { echocardiography }\end{array}$ & $\begin{array}{l}\text { Superiomedial as- } \\
\text { pect of crista } \\
\text { terminalis; mul- } \\
\text { tiple lesions over } \\
l-1.5 \mathrm{~cm}\end{array}$ & - & $95 \%$ & ?? \\
\hline
\end{tabular}

firing focal tachycardia with variable exit block, and such a focus may be ameanable to curative ablation. If atrial fibrillation can be cured in even a percentage of affected patients, it will revolutionize the field. 